\title{
Association between Multiple Sclerosis and FOXP3 Gene promoter region mutations
}

\section{Multiple Skleroz ile FOXP3 geni promotor bölge mutasyonları arasındaki ilişki}

\author{
Cekin $\mathrm{N}^{1}$, Pinarbasi $\mathbb{E}^{\mathrm{a} 1}$, Bildlirici $\mathrm{AE}^{1}$, Akin $\mathrm{S}^{1}$, Kayim Yildiz $\mathrm{O}^{2}$
}

Cumhuriyet University, Faculty of Medicine, Department of Medical Biology, Sivas, Turkey

${ }^{2}$ Cumhuriyet University, Faculty of Medicine, Department of Neurology, Sivas, Turkey

Corresponding author: Ergün Pınarbaș1, MD., Cumhuriyet University, Faculty of Medicine, Department of Medical Biology, 58140, Sivas, Turkey.

E-mail: epinar@cumhuriyet.edu.tr

Received/Accepted: April 27, 2018 / July 04, 2018

Conflict of interest: There is not a conflict of interest.

\section{SUMMARY}

Regulatory T-Cells (Treg Cells), as one of the immune system components, have been highly effective in the autoimmune diseases prevention, particularly multiple sclerosis (MS). MS is a chronic inflammatory and autoimmune disease characterized by immune infiltration and inflammation in the central nervous system. Regulatory $\mathrm{T}$ (Treg) cells play an important role in the control of autoimmunity. Expression and action of the transcription factor FOXP3 controls the development and function of Treg cell. The aim of this study was to investigate the association between MS and FOXP3 gene promoter region polymorphisms rs2232365 (-924A/G) and rs3761548 (-3279A/C) in a Turkish population. In this case-control study we investigated these polymorphisms in $80 \mathrm{MS}$ patients and 80 healthy controls using PCR-RFLP methods.

Results of our study showed that while there is significant correlation between MS and FOXP3 rs3761548 polymorphism ( $\mathrm{p}=0.031)$, FOXP3 rs2232365 polymorphism, has not been found to be associated with the disease $(\mathrm{p}=0.31)$. As FOXP3 gene is one of the most important genes in the regulation of the immune cells, it may be concluded that the expression of this gene is important in MS patients. As this SNP is located in the promoter region of the gene, it may affect the expression level of FOXP3 protein.

Keywords: Multiple sclerosis, FOXP3, polymorphism

ÖZET

Amaç: Bağıșıklık sistemi bileșenlerinden biri olan düzenleyici T (Treg) hücreleri, özellikle multiple skleroz (MS) gibi otoimmün hastalıkların önlenmesinde oldukça etkilidir. Multiple skleroz (MS), santral sinir sisteminde immün hücre infiltrasyonu ve inflamasyonla karakterize kronik inflamatuar, otoimmün bir hastalıktır. Treg hücreleri otoimmünitenin kontrolünde önemli bir rol oynar. Treg'lerin gelişimi ve ișlevi, transkripsiyon faktörü FOXP3'ün (Transkripsiyon Faktörü Forkhead Box P3) uygun ifadesine ve hareketine bağlıdır. Bu bağlamda çalışmamızın amacı, MS ve FOXP3 geni yaygın promotor bölge mutasyonlarından rs2232365 (-924 A/G) ve rs3761548 (-3279 A/C) arasındaki ilişkinin bir Türk popülasyonunda araştırılması olarak belirlenmiştir.

Yöntem: Çalışma kapsamında 80 MS hastası ve 80 sağlıklı kontrol bireyinden alınan kan örnekleri kullanılmıştır. Foxp3 genotipleri PCR-RFLP yöntemi kullanılarak belirlenmiştir.

Bulgular: Elde edilen sonuçlar istatistiksel olarak değerlendirildiğinde, MS ve FOXP3 rs3761548 polimorfizmi arasında anlamlı bir ilişski gözlenmiştir $(\mathrm{p}=0.031)$. Bunun aksine araştırılan diğer polimorfizm, rs2232365, MS hastalarında hastalıkla ilişkili bulunmamıştır $(\mathrm{p}=0.31)$. 
Sonuç: FOXP3 geni, bağış̧ılık hücrelerinin düzenlenmesinde en önemli genlerden biri olduğundan, MS hastalarında bu genin ekspresyonunun önemli olduğu sonucuna varılabilir. Bu SNP (Tek Nükleotit Polimorfizmi), genin promotor bölgesinde yer aldığından FOXP3 proteinin ekspresyon seviyesini etkileyebilir.

Anahtar sözcükler: Multiple skleroz, FOXP3, polimorfizm

\section{INTRODUCTION}

MS is a complex and multifactorial disease. A large number of genetic and environmental factors together play roles in its immunopathogenesis ${ }^{1-3}$. A series of auto immunities leading to pathology in the central nervous system and the process leading to the clinical picture is thought to begin in the peripheral immune system ${ }^{4}$. However, since a clear and homogeneous transmission pattern has not been established for MS, the classical genetic epidemiologic techniques have not been applied in studies 5 .

The regulatory $\mathrm{T}$ (Treg) cells comprise a subset of CD4+ lymphocytes that play an important role in regulating the immune response with their ability to suppress Th cells. Any defect that occurs in the Treg cells leads to the development of autoimmune diseases ${ }^{6}$. Treg cells also have important roles in the pathogenesis of autoimmune inflammation of the central nervous system; because altered Treg function and homeostasis are dangerous in terms of MS pathogenesis $^{7,8}$ and it is known that MS is a Th1/Th17-mediated autoimmune disease ${ }^{9}$. Although there is no difference in peripheral blood and cerebrospinal fluid of Treg cells in MS patients, there is considerable evidence that these cells are a problem in suppressing autoimmunity ${ }^{7}$.

The majority of the MS risk variants are located within immunologically related genes ${ }^{10,11}$. But known variants are sufficient to account for roughly $30 \%$ of the genetic basis of the disease. Many explanations have been proposed for this incomplete heritability of MS, including neglecting the analysis of sex chromosomes ${ }^{12,13}$.

Xp11.23 localized FOXP3 gene is a central molecule in the function of the Treg cells that play a role in the immunoregulation ${ }^{14,15}$. In various regions of FOXP3 gene, such as promoter, exon and intron, more than 100 SNPs (single nucleotid polymorphism) have been identified that are associated with gene expression, miRNA expression, gene splice mechanism or encoded protein structure and activity $^{16}$. The role of
FOXP3 gene polymorphisms in MS genetic susceptibility is still unclear due to the inconsistency of the result of the association studies ${ }^{17}$. In order to understand the role of FOXP3 in genetic susceptibility to MS, these inconsistencies need to be clarified. FOXP3 is an important gene, because it is located on the $\mathrm{X}$ chromosome and it encodes an effective transcription factor in the immune system. In this context, we investigated the association between MS and FOXP3 rs3761548 and rs2232365 promoter region polymorphisms in a Turkish population.

\section{MATERIAL AND METHODS}

\section{Patients}

The case group consisted of 80 patients diagnosed with MS according to McDonald criteria ${ }^{18}$ in the Neurology department of Cumhuriyet University Hospital, Sivas, Turkey. The control group was selected from 80 healthy individuals without MS and without MS in their family. The study was approved by $* * *$. An approval form was taken from the patients and control group individuals involved in the study.

\section{Genotyping}

DNA isolation was performed using the phenolchloroform method ${ }^{19}$ from $10 \mathrm{ml}$ blood samples taken from each individual. The FOXP3 promoter region was amplified by polymerase chain reaction (PCR) to include the region -924 . Forward and reverse primer sequences were 5'TGGAGGGCTTTCAAGGTGAGGA-3' and 5'GGGGAGTTGGATTGGGTGCA-3'

respectively. The method for PCR included an initial denaturing at $94^{\circ} \mathrm{C}$ for $4 \mathrm{~min}$, followed by 30 cycles at $94^{\circ} \mathrm{C}$ for $1 \mathrm{~min}, 58^{\circ} \mathrm{C}$ for $30 \mathrm{~s}, 72^{\circ} \mathrm{C}$ for $30 \mathrm{~s}$ with a final extension at $72^{\circ} \mathrm{C}$ for $10 \mathrm{~min}$. The resulting $374 \mathrm{bp}$ amplicons were incubated with BsMI (New England Biolabs) restriction endonuclease enzyme at $37^{\circ} \mathrm{C}$ for 1 hour and then separated on $3 \%$ agorose gel. For the AG genotype $374+188+186$ bp fragments, for the GG 
genotype $188+186$ bp fragments and for AA genotype 374 bp fragment were obtained following restriction digestions and agarose gel electrophoresis separation.

For FOXP3 -3279 SNP, forward and reverse primer sequences were 5'CTGACATGCCTCCATCAT-3' and 5'TGCAGGGCTTCAAGTTGACAG-3'

respectively. The method for PCR included an initial denaturing at $94^{\circ} \mathrm{C}$ for $4 \mathrm{~min}$, followed by 30 cycles at $94^{\circ} \mathrm{C}$ for $1 \mathrm{~min}, 55^{\circ} \mathrm{C}$ for $30 \mathrm{~s}, 72^{\circ} \mathrm{C}$ for $30 \mathrm{~s}$ with a final extension at $72^{\circ} \mathrm{C}$ for $10 \mathrm{~min}$. The resulting $361 \mathrm{bp}$ amplicons were incubated with Pst 1 (Nzytech) restriction endonuclease enzyme at $55^{\circ} \mathrm{C}$ for 1 hour and then separated on $3 \%$ agarose gel. For the CC genotype $138+223$ bp fragments, for the CA genotype $361+138+223 \mathrm{bp}$ fragments and for the AA genotype $361 \mathrm{bp}$ fragment were obtained following restriction digestion and agarose gel electrophoresis separation.

\section{Statistical Analysis}

The data were analyzed using the SPSS 22.0 (SPSS, Chicago, IL, USA) program. Chi square and Fisher's exact tests were used to compare the data. OR and $95 \%$ confidence intervals for obtained results were given. $\mathrm{p}<0.05$ was considered as significant in all tests.

\section{RESULTS}

Demographic data of the patient and control group were summarized in the Table 1. According to Table 1, there was no statistically significant difference in age and gender between the MS group and the control group. Only patients with bout-onset MS were included in the study: 66 individuals were classified as having relapsingremitting (RS) MS, and 14 had secondaryprogressive (SP) form.

Table 1: Demographic data of MS patients and controls.

\begin{tabular}{lcc}
\hline Demographic data & Control $(\mathbf{n = 8 0})$ & Patients $(\mathbf{n}=\mathbf{8 0})$ \\
\hline Age & $37.9 \pm 8$ & $40.9 \pm 10.6$ \\
Gender & $52(\% 65)$ & $55(\% 68.75)$ \\
$\quad$ Female & $28(\% 35)$ & $25(\% 31.25)$ \\
$\quad$ Male & & $9 \pm 5$ \\
Disease duration (years) & \\
MS form & \\
$\quad$ RR & $66(\% 82.5)$ \\
$\quad$ SP & $14(\% 17.5)$
\end{tabular}

MS: multiple sclerosis, RR: relapsing-remitting, SP: secondary progressive

When genotype distribution of the patient and control group is examined in terms of FOXP3 gene promoter region rs2232365 polymorphism, there was no statistically significant difference in genotype and allele frequency between the patient and control group for this polymorphism. The distributions for rs2232365 obtained from MS patients and healthy control group are summarized in Table 2. 
Table 2: Distribution of genotypes and allele frequencies of FOXP3 gene promoter region polymorphism rs2232365 among patients with MS and healthy subjects

\begin{tabular}{lllll}
\hline & Control $(\mathbf{n}=\mathbf{8 0})$ & Case $(\mathbf{n}=\mathbf{8 0})$ & p value & OR(\% 95CI) \\
\hline Genotype & & & & \\
AA & $44(\% 55)$ & $34(\% 42.5)$ & & \\
AG & $20(\% 25)$ & $23(\% 28.75)$ & 0.3 & $1.483(0.699-3.169)$ \\
GG & $16(\% 20)$ & $23(\% 28.75)$ & 0.12 & $1.85(0.8474-4.102)$ \\
Genotype & & $34(\% 42.5)$ & & \\
AA & $44(\% 55)$ & $46(\% 57.5)$ & 0.12 & $1.648(0.8815-3.102)$ \\
AA+AG & $36(\% 45)$ & & & \\
Allele & & $91(\% 56.87)$ & & \\
A & $108(\% 67.5)$ & $69(\% 43.13)$ & 0.05 & $1.573(0.9974-2.488)$ \\
G & $52(\% 32.5)$ & & & \\
\hline
\end{tabular}

When the case and control groups were compared in terms of rs3761548, it was determined that heterozygous AC genotype and homozygous CC genotype showed a significant difference between
MS patients and healthy individuals. The association between FOXP3 rs3761548 polymorphism and MS disease is shown in Table 3.

Table 3: Distribution of genotypes and allele frequencies of FOXP3 gene promoter region polymorphism rs3761548 among patients with MS and healthy subjects

\begin{tabular}{lllll}
\hline & Control $(\mathbf{n}=\mathbf{8 0})$ & Case $(\mathbf{n}=\mathbf{8 0})$ & p value & OR(\%) 95CI) \\
\hline Genotype & & & & \\
AA & $44(\% 55)$ & $12(\% 15)$ & & \\
CC & $12(\% 15)$ & $28(\% 35)$ & $\mathbf{0 . 0 2 6}$ & $7.671(1.248-60.19)$ \\
Genotype & $24(\% 30)$ & $40(\% 50)$ & $\mathbf{0 . 0 3 1}$ & $5.714(1.157-34.97)$ \\
AA & $44(\% 55)$ & $12(\% 15)$ & & \\
CC+AC & $36(\% 45)$ & $68(\% 85)$ & $\mathbf{0 . 0 1}$ & $6.568(1.511-36.03)$ \\
Allele & & $100(\% 62.5)$ & & \\
A & $52(\% 32.5)$ & $60(\% 37.5)$ & $\mathbf{0 . 0 0 8}$ & $3.405(1.362-8.806)$ \\
C & $108(\% 67.5)$ & & & \\
\hline
\end{tabular}

\section{DISCUSSION}

More than hundred new MS risk SNPs in more than 100 loci have been discovered by development of genome wide association studies (GWAS) and subsequent Immuno-chip based studies in recent years ${ }^{20}$. In the pathogenesis and complications of MS disease, immune system, the appearance of autoimmunity in the pathogenesis, damage to peripheral immunological tolerance, play important roles ${ }^{21,22}$. In some mouse models, 
Treg cells have been shown to provide a critical level of protection against autoimmunity, transplant rejection and lymph-proliferative diseases $^{23}$. FOXP3 gene encodes a transcription factor believed to be crucial for the development and function of the Treg cells ${ }^{14}$. Recent studies have confirmed that the suppressive function of regulatory $\mathrm{T}$ cells (Treg) is impaired in MS patients and that the FOXP3 gene is a crucial transcription factor in the regulation of $\mathrm{CD}^{+} \mathrm{CD} 25^{+} \mathrm{FOXP}^{+}{ }^{+}$Treg cells. Polymorphisms in the promoter region of the FOXP3 gene may alter the gene expression level and, therefore, contribute to the disease susceptibility ${ }^{5,24,25}$.

In our study, the genetic association between two common polymorphisms of the FOXP3 gene promoter region (rs2232365 and rs3761548) and susceptibility to MS disease was evaluated in a Turkish population. As a result, while there was no significant difference in the rs2232365 polymorphism, for rs3761548 the homozygous genotype, heterozygous genotype and polymorphic allele were found to be higher in MS patients than in healthy controls (see Table 3 ).

In 2005, Huan and colleagues examined the level of FOXP3 expression in MS patients and found that MS patients expressed FOXP3 at varying low levels ${ }^{26}$. In following years, Jafarzadeh and colleagues conducted a study on FOXP3 polymorphisms in Iranian population and rs3761548 AA and AC genotype frequencies were found to be statistically significantly higher in MS patients compared to healthy control subjects. When they examined in terms of allele frequencies, in MS patients, the frequency of A allele was significantly higher and the frequency of $\mathrm{C}$ allele was found to be significantly lower than control subjects ${ }^{27}$. Similarly, in the study of polymorphism in Iranian populations, Eftekharian et al reported that rs3761548 polymorphism may be associated with MS susceptibility ${ }^{28}$. In our study, like another studies, there is an association between rs3761548 polymorphism and MS phenotype. In contrast to these data, the another study with Iranian population did not show a significant association between rs3761548 and MS disease susceptibility ${ }^{29}$. And also, in a study conducted in Slovak population in 2017, it was also stated that there was no significant association between rs3761548 polymorphism and genetic predisposition to MS disease. Furthermore, they found that polymorphism allele frequencies did not significantly differ between patients and control groups independent from gender. Gajdobsechova and colleagues pointed out that there is no evidence that FOXP3 gene polymorphisms are associated with MS in European origin Caucasian population, consistent with the results of these studies, with reference to two GWAS studies in MS for their study results ${ }^{17}$.

The last two studies in Iranian population in case of disagreement about rs3761548 polymorphism have suggested that rs2232365 polymorphism may support MS susceptibility ${ }^{28,29}$. In contrast these findings, in our study, there is no association between rs2232365 polymorphism and MS susceptibility while rs3761548 polymorphism supported MS phenotype.

These inconsistent observations between different populations and even the same ethnic groups are due to various factors such as especially the genetic differences among ethnic groups, inadequate sample size, the power of statistical analysis, the risk of false positive results, differences between the inclusion or exclusion criteria for selected individuals in the patients and control groups, the design of the study and the statistical approach it explained. Therefore, to better understand the actual effects of FOXP3 variants on the disease susceptibility and process, in a larger sample, there is a need for further research that evaluates in terms of functional and genetic, considering both other polymorphisms in the promoter region and other regions of the gene, as well as other parameters of the disease.

\section{REFERENCES}

1. Hafler DA, Slavik JM, Anderson DE, O'Connor KC, De Jager P, Baecher-Allan C. Multiple sclerosis. Immunol Rev, 2005; 204:208-231.

2. İdiman E. Multipl skleroz'un immünopatogenezi. Türkiye Klinikleri $J$ Neur, 2004; 2:171-176.

3. Weissert R. The immune pathogenesis of Multiple sclerosis. Pharmacol, 2013; 8:857-866.

4. Piccirillo AC, Shevach ME. Naturally occuring CD4(+)CD25(+) immunoregulatory $\mathrm{T}$ cells: central players in the arena of peripheral tolerance. Semin Immunol, 2004; 16(2):81-88.

5. Işık N, Yıldız-Manukyan N, AydınCantürk İ, Candan F, Ünsal-Çakmak A, Saruhan-Direskeneli G. Multipl skleroza genetik yatkınlı: Foxp3 gen 
polimorfizmin rolü. Nöropsikiyatri Arşivi, 2014; 51:69-73.

6. Singer BD, King LS, D'Alessio FR. Regulatory $\mathrm{T}$ cells as immunotherapy. Front Immunol, 2014; 5:46.

7. Viglietta V, Baecher-Allan C, Weiner HI, Hafler DA. Loss of functional supression by $\mathrm{CD} 4+\mathrm{CD} 25+$ regulatory $\mathrm{T}$ cells from patients with Multiple sclerosis. J Exp Med, 2004; 199:971-979.

8. Yadav SK, Mindur JE, Ito K, Dhib-Jalbut S. Advances in the immunopathogenesis of Multiple sclerosis. Curr Opin Neurol, 2015; 28:206-219.

9. Aranami T, Yamamura T. Th17 cells and autoimmune encephalomyelitis (EAE/MS). Allergo Int, 2008; 57:115120.

10. Dendrou CA, Fugger L, Friese MA. Immunopathology of Multiple sclerosis. Nat Rev Immunol, 2015; 15:545-558.

11. Bos SD, Berge T, Cellus EG, Harbo HF. From genetic associations to functional studies in Multiple sclerosis. Eur $J$ Neurol, 2016; 23:847-853.

12. Chang D, Gao F, Slavney A, Ma L, Waldman YY, Sams AJ, et al. Accounting for eXentricties: analysisof the $X$ chromosome in GWAS reveals X-linked genes implicated in autoimmune diseases. Plos One, 2014; 9:e113684.

13. Hollenbach JA, Oksenberg JR. The immunogenetics of Multiple sclerosis: A comprehensive review. J Autoimmun, 2015; 64:13-25.

14. Oda JMM, Hirata BKB, Guembarovski RL, Watanabe MAE. Genetic polymorphism in FOXP3 gene: imbalance in regulatory T-cell role and development of human diseases. J.Genet. 2013; 92:163-171.

15. Katoh H, Zheng P, Liu Y. Foxp3: genetic and epigenetic implications for autoimmunity. $J$ Autoimmun, 2013; 41:72-78.

16. Marques CR, Costa GN, da Silva TM, Telxira TO, de Andrade EM, et al. Genetic and epigenetic studies of Foxp3 in asthma and allergy. Asthma Res Pract, $2015 ; 1: 10$.

17. Gajdosechova B, Javor J, Cierny D, Michalik J, Durmanova V, Shawkatova I, Parnicka Z, et al. Association of Foxp3 polymorphisms rs3761547 and rs3761548 with Multiple sclerosis in the Slovak population. Act Nerv Super Rediviva, 2017; 59(1):9-15.
18. Polman $\mathrm{CH}$, Reingold SC, Edan G, Filippi M, Hartung HP, Kappos L, Lublin FD, Metz LM, McFarland HF, O'Connor PW, Sandberg-Wollheim M, Thompson AJ, Weinshenker BG, Wolinsky JS. Diagnostic criteria for Multiple sclerosis: 2005 revisions to the "McDonald Criteria". Ann Neurol, 2005; 58:840-846.

19. Ullrich A, Shine J, Chirgwin J, et al. Rat insülin genes: construction of plasmids containing the coding sequences. Science, 1977; 196(4296):1313-1319.

20. International Multiple Sclerosis Genetic Consortium (IMSGC), Beecham AH, Patsopoulos NA, Xifara DK, Davis MF, Kemppien A, et al. Analysis of immunerelated loci identifies 48 new susceptibility variants for Multiple sclerosis. Nat Genet, 2013; 45:1353-1360.

21. Graber J, McGraw C, Kimbrough D, Dhib-Jalbut S. Overlapping and distinct mechanisms of action of Multiple sclerosis therapies. Clin Neurol Neurosurg, 2010; 112:583-591.

22. Men $M$, Kutlu $C$, İlhan-Algın $D$, Gülbaş Z. The $\mathrm{Cd} 4(+) \mathrm{Cd} 25(+)$ regulatory $\mathrm{T}$ cell profile and Foxp3 expression and clinic associations of in various stage and types of Multiple sclerosis. Osmangazi Journal of Medicine, 2018; 40(1):7-13.

23. Coffer PJ, Burgering BMT. Forkhead-box transcription factors and their role in the immune system. Nat Rev, 2004; 4:889899.

24. Gagliani N, Jofra T, Valle A, Stabilini A, Morsiani C, Gregori S, Deng S, Rothstein DM, Arkinson M, Kamanaka M, Flavell RA, Roncarolo MG, Battaglia $M$. Transplant tolerance to pancreatic islets is initiated in the graft and sustained in the spleen. Am $J$ Transplant, 2013; 13(8):1963-75.

25. Koyama M, Kuns RD, Olver SD, Lineburg KE, Lor M, Teal BE, Raffelt $\mathrm{NC}$, Levegue $\mathrm{L}$, Chan $\mathrm{CJ}$, et al. Promoting regulation via the inhibition of DNAM-1 after transplantation. Blood, 2013; 121(17):35111-20.

26. Huan J, Culbertson N, Spencer L, Bartholomew R, Burrows GG, Chou YK, Bourdette D, Ziegler SF, Offner H, Vandenbark AA. Decreased Foxp3 levels in Multiple sclerosis patients. Journal of Neuroscience Research, 2005; 81:45-52.

27. Jafarzadeh A, Jamali M, Mahdavi R, Ebrahimi HA, Hajghani $H$, Khosravimashizi A, Nemati M, 
Najafipour H, Sheikhi A, Mohammadi MM, Daneshvar H. Circulating levels of interleukin-35 in patients with Multiple sclerosis: evaluation of the influences of Foxp3 gene polymorphsism and treatment program. J Mol Neurosci, 2015; 55:891897.

28. Efekharian MM, Sayad A, Omrani MD, Ghannad MS, Noroozi R, Mazdeh M, et al. Single nucleotide polymorphisms in the Foxp3 gene are associated with incrased risk of relapsing-remitting multiple sclerosis. Hum Antibodies, 2016; doi: 10.3233/HAB-160299.

29. Gholami M, Darvish H, Ahmadi H, Rahimi-Aliabadi S, Emamalizadeh B, Eslami Amirabadi MR, et al. Functional genetic variants of Foxp3 and risk of multiple sclerosis. Iran Red Crescent Med $J$, 2016; e34597. 